\title{
Graphic Novels in Curriculum and Instruction Collections
}

Graphic novel collection and use has become a popular topic in the library community; most of the literature has focused on collecting in school and public libraries. The number of academic libraries that carry graphic novels has increased, but those collections and the few articles addressing graphic novels in academic librarianship have focused on serving the recreational reader or the pop culture historian. Meanwhile, the education community has begun to embrace graphic novels as a way to reach reluctant readers; engage visual learners; and improve comprehension and interpretation of themes, literary devices, and social issues, among other topics. As graphic novels are increasingly used in the classroom, students majoring in elementary and secondary education should have access to these materials as they prepare for their future careers. Making graphic novels a specific part of the curriculum and instruction collection supports the academic library's mission to meet the research and training needs of the faculty, staff, and students.

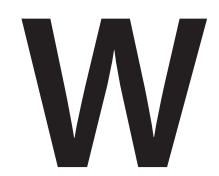
hile there has been a much greater focus on graphic novels in the library literature over the last decade, most coverage has been limited to school media centers and public libraries. Published research about graphic novel collections in academic libraries has been limited to investigating the genre as either recreational reading for busy college students or as part of the cultural and historical record. There is still resistance to the genre in some circles; combining text and images is considered fine for children's books, but children are expected to "grow out of it" and start reading "real books." The experienced graphic novel enthusiast will use both text and image in their reading, cognition, and translation of the work, but those unfamiliar with the format and how it is read will more likely skim the novel, focus more on the images themselves than the context of those images, and misinterpret the intent of the artist and author. This leads to complaints about portrayals of violence, sex, misogyny, antiauthoritarianism, and other controversial or sensitive topics, as well as concern about underage patrons' access to such. ${ }^{2}$ There also is the assumption that graphic novels are too "easy," or that pictures detract from what the authors could have expressed in words alone. $^{3}$

However, graphic novels today are being used increasingly by educators to engage reluctant readers, reach out to visual learners, and illustrate social and cultural themes and topics. Districts are
Elizabeth M. Downey

Elizabeth M. Downey is Assistant Professor and Instructional Services Librarian, Mississippi State University Libraries, Mississippi State, Mississippi. Submitted for review January 4, 2009; accepted for publication March 3, 2009.

Reference \& User Services Quarterly, vol. 49 , no. 2 pp. 181-188

(c) 2009 American Library Association. All rights reserved.

Permission granted to reproduce for nonprofit, educational use. 
now seeing the benefits of these tools: The New York City Department of Education began promoting and supporting graphic novel use in their classrooms in spring 2008 by training hundreds of the city's school media specialists. The in-service sessions focused on selection, lesson plans, and graphic novels as a tool to draw students to the library. ${ }^{4}$ Part of the academic library's mission is to provide materials and resources for future educators. Academic libraries should carry graphic novels in their collections for pleasure reading by students and faculty, to serve as examples of modern art and graphic design, and for historical value; but they also should be included in subjectspecific curriculum and instruction collections for education majors preparing for practicum and developing lesson plans.

\section{LITERATURE REVIEW}

A review of the library and information science literature indicates that not much has been published in regards to graphic novels in academic libraries outside of the occasional book review or highlight of a special collection. There are a few notable exceptions: O'English, Matthews, and Lindsay provide an overview that covers several subtopics and issues, including graphic novels as literature, their increasing popularity in libraries, endorsement of the format as pleasure reading for students and faculty, collection development, cataloging and classification, and promotion and outreach in academia. There is one section devoted to outreach to preservice teachers, which encourages marketing the format to education departments and colleges. It states that graphic novels appeal to the visually literate and the reluctant reader, and are useful in illustrating story structure in writing exercises. ${ }^{5}$

A short piece published in Indiana Libraries describes a collaborative research project between Avon (Ind.) High School's library media specialist Robyn Young and the library school at Indiana University-Indianapolis. Young wanted to see if reading graphic novels improved "overall academic achievement and reading comprehension," which might lead to higher overall scores on the Indiana Statewide Testing for Educational Progress (ISTEP), the statewide standardized exit exam. ${ }^{6}$ She teamed with a faculty member from her former SLIS program to conduct a study with special education students. While the article is not about collections in an academic library, it does illustrate the value of partnerships between the academic and school library community.

More recently, Williams and Peterson conduct- ed a content analysis, examining the collections of academic institutions that supported National Council for Accreditation of Teacher Education and American Library Association-accredited programs. The authors checked for works appearing in the 2007 and 2008 "Great Graphic Novels for Teens" list released annually by the Young Adult Library Services Association (YALSA). They also looked for variations in the collections by geography, collection size, and Carnegie institution classification. Their study showed that larger institutions on average held more graphic novels on the YALSA lists and that graphic novels were more likely to be in the holdings of doctoral and research universities, schools with library science programs, or institutions located in the western United States. However, it also revealed that a considerable number of institutions supporting library science or education programs aren't actively collecting graphic novels for teens. While the parameters of the study did not include older titles not appearing on the YALSA lists, the results illustrate the need for those libraries to evaluate their current holdings. ${ }^{7}$

Most of the library literature that addresses graphic novels appears in journals whose primary audience is school media center, young adult, and children's services librarians. An additional assessment of the primary and secondary education and curriculum literature produced many more results dealing with the use of graphic novels in $\mathrm{K}-12$ classrooms. In these articles, some distinct themes came to the surface: the concept of "visual literacy," the use of graphic novels in reading comprehension, the graphic novel as a comparative tool paired with traditional texts, and the graphic novel as a lens to examine topics of conflict, culture, and prejudice. Many examples of these themes, including specific descriptions of how graphic novels have been utilized in lesson planning, are detailed further in this article.

\section{WHY GRAPHIC NOVELS IN CURRICULUM?}

There are several arguments for introducing graphic novels into the classroom. Teachers can use them as stand-alone texts or as part of a larger curriculum by connecting the themes and ideas in graphic novels to bigger topics and making those connections more effective. ${ }^{8}$ The graphic novel itself has educational value as a pop culture medium. Schwarz writes, "In any subject area, studying a graphic novel can bring media literacy into the curriculum as students examine the medium itself. Students can explore such questions as how color 
affects emotions, how pictures can stereotype people, how angles of viewing affect perception, and how realism or the lack of it plays into the message of a work." In a broader sense, writes Allender, "popular culture has affective and academic value. It should be used in a variety of ways as one would use texts generally in a constructivist, cultural studies classroom concerned with student achievement and transformative learning." ${ }^{10}$ More specifically, graphic novels are useful tools in classrooms where students are primarily visual learners. They illustrate cognitive and literary concepts resulting in stronger comprehension of the materials. They also have a social use, introducing students to diverse peoples and cultures they might otherwise not encounter. Ultimately, the main goal is to grow a literate populace by using inventive methods to promote a lifetime reading habit. ${ }^{11}$

Today's students have had a childhood filled with the rapid pace and visual stimulation of television and video games, and they therefore seek the same characteristics in their reading materials: a scaled-down approach featuring short narratives and graphic indicators. ${ }^{12}$ Educators are adapting to this new reality: Laura Mullen, an English professor at Louisiana State University, was quoted in the campus newspaper as saying "We're all of the Internet now. ... we never get a word without an image going with it, so in fact I think this is the direction of our future reading comprehension. It will include both visual literacy and verbal literacy." ${ }^{13}$ In addition to this excess of images and graphics within the media in young people's lives, standardized tests include visual elements as part of assessment. Some students simply are not capable of conjuring images in their mind from reading the text and therefore are dependent on visual cues; graphic novels provide images that help the students interpret the text as well as denote particular thematic connotations, purposes, or ideas. ${ }^{14}$ To take this idea further, Thompson writes that one of the chief rewards of using these books is how the images actually model the visualization most text-based learners do while reading; they "work interdependently with the text and offer a symbiotic example of what good readers do to create mental images as they read." ${ }^{15}$ Leckbee adds that the graphic novel is a distinctive tool teachers can use to spark interest in learning and facilitate functional literacy. ${ }^{16}$ Gretchen Schwarz has written extensively on the topic and calls the genre "a new medium for literacy that acknowledges the impact of visuals." 17

Beyond simply offering an option to visual learners, all students may benefit from the effect reading graphic novels has on comprehension skills. When Will Eisner, thought of in the comic world as the father of the graphic novel, invented the term "sequential art" to describe comic books, the implication was that "the perception of sequential art requires more complex cognitive skills than the reading of text alone." ${ }^{18}$ To that end Lyga and Lyga argue that of the seven multiple intelligences identified by Harvard psychologist Howard Gardner, three of them (linguistic, spatial, and interpersonal) can benefit from the use of graphic novels. ${ }^{19}$ The most recent "best practices" in literacy acknowledge the value of reading in a wide variety of styles and levels on comprehension. ${ }^{20}$ Graphic novels are also helpful in examining literary elements such as plot, scenery, character, premise, conflict, as well as devices such as simile, metaphor, and exaggeration. They can be used to develop deductive reasoning abilities, an advanced thinking level according to Bloom's taxonomy. ${ }^{21}$ They also are perceived as less threatening by overwhelmed students, and the pictures can help them grasp the meaning of the content, learn new vocabulary words, advance the narrative, and be more motivated to read. ${ }^{22}$ The novels can illustrate sequencing, placement, and timing of dialogue; they also may introduce students to new subjects, leading them to seek out other similarly themed nonpicture books on the same topic. ${ }^{23}$ In the same vein, graphic novel versions of famous literary works may spur students to seek out the original prose version. ${ }^{24}$

In addition to the technical aspects of learning that can be enhanced by the use of graphic novels in the classroom, broader social lessons can be illustrated. Graphic novels and comics are often a reflection of the creator's culture and upbringing. Traditional storytelling elements are not lost within these novels, but improved by the moral foundation and unique viewpoint of the artist. In numerous cases, students find a personal connection they otherwise may not find in a traditional text. ${ }^{25}$ Graphic novels grab the attention of students by staying on the cutting edge and often reflect current events and societal changes before other forms of media can. For instance, within a month after the events of September 11, Marvel Comics announced that it would release a commemorative magazine titled Heroes, and that all of the proceeds would benefit the families of fallen firefighters. ${ }^{26}$ Graphic novels put forward different opinions and notions of society, history, traditions, and life in a more straightforward manner and give minority viewpoints a voice. ${ }^{27}$ They also can assist in filling disparities in academic achievement between different races, ages, and genders. ${ }^{28}$ Graphic novels also may serve as models for the realistic use of 
colloquial phrases and slang terms for new learners of English. ${ }^{29}$

\section{EXAMPLES OF USE}

There are numerous examples of graphic novels being used in middle and high school curricula. Leckbee uses the Art Spiegelman graphic novel Maus as part of a unit she teaches on the Holocaust in her English classes at Akins High School in Austin, Texas. The students are given a "brochure assignment" where they are asked to put themselves in the shoes of one of the characters; they are to follow that character, draw comparisons and similarities to their own lives, and write diary entries for that character that are based on events in the book. The purpose of this assignment is to bring the Holocaust experience closer to the student. ${ }^{30}$ She also teaches a section on compassion using the graphic novel Family Matter written by Will Eisner paired with John Steinbeck's novel of Mice and Men, and she uses traditional superhero comics to illustrate the Hero Cycle and demonstrate the concepts of genre and subgenre. Leckbee points out that graphic novels present opportunities to examine different types of reading. For example, the Japanese style known as Manga is read from bottom right to upper left, the exact opposite of traditional English panel comics. She gave her students a "multiple intelligences project" to carry out on a graphic novel of their choosing; the students could then consider how they are written, the artistic method, and the author's aim. ${ }^{31}$

Frey and Fisher documented their experiences using graphic novels as well as other popular media while teaching a ninth-grade writing course in a primarily urban setting. They began by using Will Eisner's work New York: The Big City as a group reading, showing visual storytelling techniques and coming up with descriptors while discussing the work. The students were then told to write the story they saw, resulting in many interpretations and responses. ${ }^{32}$ Encouraged, they continued this method of instruction with more graphic novel excerpts, teaching ways to indicate speech, convey "shades of meaning," and effectively express several ideas within just a couple of sentences. ${ }^{33}$ This method of "scaffolding" writing projects was useful in giving the students opportunities to hone their writing craft leading up to their ending project, an original illustrated narrative using original art and photographs they took themselves. ${ }^{34}$

Carter recounts teaching Ultimate Spider-Man Volume 1: Power and Responsibility to middle school, high school, and college students, and how it serves as a metaphor for the onset of adolescence, leading to lengthy discussions at all class levels. ${ }^{35}$ He also discusses the use of Maus, specifically how other teachers have drawn on its themes in different subject areas. ${ }^{36}$ He notes that Barbara Brown used panels that discussed and portrayed racism to facilitate an analysis of race relations in William Faulkner's Light in August and in the students' day to day lives. ${ }^{37}$ Andrea Freud Loewenstein used Maus to explain hostility between the African Caribbean and Lubavitcher Jewish communities in the Brooklyn neighborhood of Crown Heights. ${ }^{38}$ In addition to teaching in the K-12 system, Carter also is a college instructor in English education. He has used graphic novels in the context of vocabulary, composition, and comprehension for younger students, and he imparts those lessons to his licensure students-altering their notions and definitions of literacy-and teaches them how to use graphic novels in the classroom. ${ }^{39}$

Carter recommends three approaches for English teachers who want to incorporate graphic novels into their classes. One is the cross-curricular approach, pairing with a history or social studies class and using titles that discuss political or social issues. ${ }^{40}$ Another approach is the use of graphic novels to complement traditional texts to enhance comprehension and analysis-one could link $\mathrm{Na}$ thaniel Hawthorne's The Scarlet Letter with Katherine Arnoldi's The Amazing True Story of a Single Teenage Mom; or assign Ralph Ellison's Invisible Man with the comic Truth: Red, White and Black, a reimagining of the Captain America saga where the formula that made Steve Roger into a superhero was first tested on African American soldiers and that the first captain was a black man. ${ }^{41}$ The third approach is to use "contact zone theory"; in this, teachers and students are asked to look at current events and controversial topics from a variety of viewpoints and belief systems and then engage in a discussion utilizing those views; Carter has used novels by Alan Moore to discuss terrorism and September 11, and Chris Ware to explore the concept of family. ${ }^{42}$

Ian Carlson uses comics in his Advanced Placement English classes. He begins his graphic novels sections by first showing them an image from a graphic novel outside the context of the novel itself, and asks the students their observations. The questions he posits are comparable to those used in traditional literary analysis, and once the students make that connection, they are given the full graphic novel (or passage) from which the image was taken, which leads to further discussion and analysis. ${ }^{43}$ 
The use of graphic novels is not limited to English writing and literature courses. Crawford recommends graphic novels as supplemental reading to help meet social studies standards: "A central purpose of social studies is to promote civic competence and provide young people with the necessary skills and knowledge to become informed citizens." ${ }^{\prime 4}$ The National Council of Social Studies (NCSS) developed a set of standards for teachers to meet that purpose-they are ten themed multidisciplinary subjects that include social sciences, humanities, and hard sciences. Two of those NCSS standards are "Individual Development and Identity" and "Power, Authority and Governance." ${ }^{45}$ Crawford suggests titles that aim for those standards, including novels dealing with war, bigotry, homophobia, HIV, anti-Semitism, and identity issues. ${ }^{46}$

The idea of using graphic novels within curriculum also is expanding beyond the $\mathrm{K}-12 \mathrm{com}$ munity. Universities are adopting graphic novels in different ways, from summer reading programs to composition courses. In March 2008, Louisiana State University announced that their Summer Reading Program selection, a suggested book for incoming freshmen in addition to other students, faculty, and staff, would be a graphic novel. Marjane Satrapi's The Complete Persepolis, an autobiography about the author's childhood in Iran after the 1979 Islamic revolution, was chosen by a committee of more than twenty faculty and students. A faculty member said that one intention of choosing a graphic novel was precisely because it was different, and that "that's part of reading in college and learning to read different texts." ${ }^{47}$

In addition to anecdotal evidence of the success of using graphic novels in the classroom, scientific data is supporting the value in using the format. Research studies have been conducted to determine the effectiveness of graphic novels' use: Young's study of test scores and graphic novels previously discussed is just one example. ${ }^{48}$ Mallia conducted experiments to determine if "comics could be a cognitive tool as effective as text and illustrated text" by making three different renderings of the same story: a version with only text, one with a few illustrations to complement the text, and one in a traditional paneled comic style. ${ }^{49}$ Thirty students each were given the text-only, textwith-illustration, or comic versions and then asked a series of questions to test their recall, retention, and comprehension of the story; the data analyzed showed no significant difference in the test scores and that the comic version was just as effective in conveying the story as the two more traditional versions. ${ }^{50}$

\section{COLLECTION DEVELOPMENT}

Selection criteria for a graphic novel collection geared toward supporting curriculum and instruction programs will be somewhat different from the criteria used for a collection for recreational or special collections/historical use. Materials in an educational collection will be used to familiarize student teachers with graphic novels as either required or supplemental reading and for constructing lesson plans. For starters, collection development librarians should read the K-12 education literature, specifically looking for lesson plans based on graphic novels, and learn not only what graphic novel titles are being utilized in the classroom, but how they are being utilized. In addition to graphic novels themselves, supplemental materials such as books and websites containing specific lesson plans or traditional texts that pair well with graphic books should be considered.

Michael Lavin, in a 1998 Serials Review article, offered ten basic rules for collection development librarians to consider when selecting graphic novels for a collection. These rules were broad and geared toward general collections, but some of his criteria (such as suitability, age level, genre, and awards received) can specifically be tailored for curriculum and instruction collections. ${ }^{51}$ Lavin's suggestions can be combined with those from Lyga and Lyga - they also list grade, reading level, age appropriateness, and suitability as key guidelines in selecting titles. ${ }^{52}$ Many graphic novels are geared toward students in middle and high school, and certain concepts or plot points that aren't considered explicit in the written word, may seem more so when illustrated. ${ }^{53}$ H.W. Wilson's Graphic Novels Core Collection database includes notations in the abstracts indicating appropriateness for certain ages and the presence of adult language, violence, and sexual themes or images.$^{54}$ The quality of the graphic novel also is an important trait to consider-both writing and artistic quality should be examined, and reputation of the author or illustrator and awards also may be factors. ${ }^{55}$ Subject matter and curricular connections in particular are of extreme importance to a curriculum and instruction collection. ${ }^{56}$ Consider the popularity of the title in question in lesson plans and school media centers.

Some appropriate selection tools are specifically recommended to educators. Daniel Barron, in a 1991 article, suggests materials to teachers who want to incorporate comics into their lesson plans, such as articles on the use of comics and graphic novels in teaching reading comprehension, cultural criticism, and promotion of nongraphic ma- 
terials. Many of these materials are very relevant today. ${ }^{57} \mathrm{He}$ also recommends Jim Thomas's Cartoons and Comics in the Classroom: A Reference for Teachers and Librarians, which includes techniques to further cultural, informational, and functional literacy and creative thinking in subjects such as "economics, Latin and French, science, writing, art, and history," and ways that comics can be used to teach special-needs students..$^{58}$

There are many tools available on the Web and through paid subscription databases to assist in selecting graphic novel titles. H.W. Wilson offers its Graphic Novels Core Collection subscription database to public libraries, colleges, universities, and school media centers. It includes approximately two thousand suggested titles with brief descriptions, annotations, partial reviews, awards, and images, and the entries are searchable "by author, title, subject, genre and grade [or reading] level. ${ }^{159}$ Graphic Novels Core Collection was named one of the "10 Best Digital Resources" by School Library Journal in $2008 .{ }^{60}$ Reviews of graphic novel titles also are available in publications such as School Library Journal, Publisher's Weekly, Library Journal, and Teacher Librarian-these and other titles are indexed in H.W. Wilson's Library Literature and Information Science Full Text and EBSCO's Library, Information Science and Technology Abstracts (LISTA). ${ }^{61}$ Articles recommending both print and online resources also are plentiful in the literature. ${ }^{62}$

Several free resources are available online to aid in the selection of graphic novels and supporting materials, including research and subject guides from university library webpages. These guides include recommended review sites, discussion lists, publishers, and bibliographies. ${ }^{63}$ The discussion list GNLIB: Graphic Novels in Libraries, is a good way to stay current with graphic novels news and network with other librarians who use them. ${ }^{64} \mathrm{~A}$ curriculum and instruction collection that includes graphic novels also should contain supplemental materials, including reference books. Lesson plans are included in Lyga and Lyga's Graphic Novels in Your Media Center: A Definitive Guide, and a few sample lesson plans can be found in education journals such as Knowledge Quest, English Journal, the Journal of Basic Writing, and Instructor. Carter, however, says there is a "dearth of essays on specific graphic novel titles in . . journals" and that "more teachers and scholars need to publish lesson plans and articles on their experiences with these books and recommend other acceptable titles as they try them." ${ }^{\prime \prime 5}$

When it comes to sources for purchasing graphic novels, much of the literature offerings in the past suggested going to local comic book specialty stores and comic publishers; however, now vendors such as Baker and Taylor, Brodart, and Ingram include graphic novels in their offerings and may even be able to provide MARC records for cataloging and access. ${ }^{66}$ Academic vendors like Blackwell and YBP also are feeling increasing demand for graphic novels from their academic clients (YBP customers can go through Baker and Taylor). ${ }^{67}$ Blackwell reports that it can create approval profiles for graphic novels from its own subject code or Library of Congress Code Z692.67; there are currently no selection lists based on award winners (the Eisners, Harveys, Ignatzs, etc.) or YALSA's Great Graphic Novels for Teens list. ${ }^{68}$ But those award and recommendation lists can serve as practical selection tools when ordering. Diamond Comic Distributors works with book vendors and sells directly to school libraries, maintaining a website specific to schools (http:// bookshelf.diamondcomics.com) that, in addition to ordering information, contains reviews and lesson plans for educators. ${ }^{69}$

\section{CONCLUSION}

Graphic novels have become mainstream and are gaining increasing acceptance in the academy. In the last twenty years the literature in support of graphic novels in academic collections has grown, and the reasoning behind such collections has become more complex. What was once disregarded as a lower form of literature has evolved into pop culture artifact, then into a tool to lure the reluctant reader, and now a medium to increase literacy, comprehension, knowledge, and creative thinking. Perhaps the realization that there are different ways of learning has contributed to this rethinking of the graphic novel. As the literature shows, more teachers are discovering graphic novels and incorporating them into their lessons. Someday graphic novels may be included in state textbook plans and curriculum standards. As school districts, educators, and school librarians promote the use of graphic novels as part of the K-12 curriculum, academic libraries need to be adding graphic novels and supporting reference materials specifically to their curriculum and instruction collections as well as provide outreach, collaboration, and instruction opportunities to provide for the training of future educators.

\section{References}

1. Scott McCloud, Understanding Comics: The Invisible Art (New York: HarperPerennial, 1994): 139-40.

2. Francesca Goldsmith, Graphic Novels Now: Building, 
Managing, and Marketing a Dynamic Collection (Chicago: ALA, 2005): 86.

3. Jodi Leckbee, "I Got Graphic! Using Visual Literature Works!" Young Adult Library Services 3, no. 4 (Summer 2005): 30.

4. "Cred for Comics," School Library Journal 54 no. 6 (Jun. 2008): 16.

5. Lorena O'English, J. Gregory Matthews, and Elizabeth Blakesley Lindsay, "Graphic Novels in Academic Libraries: From Maus to Manga and Beyond," Journal of Academic Librarianship 32, no. 2 (Mar. 2006): 179.

6. Robyn Young, "A Collaborative Effort: Importance of the Relationship Between School Libraries and The University," Indiana Libraries 25, no. 3 (2006): 16.

7. Virginia Kay Williams and Damen V. Peterson, "Graphic Novels in Libraries Supporting Teacher Education and Librarianship Programs," Library Resources and Technical Services 53 no. 3 (July 2009): 166-73.

8. Allison A. W. Lyga and Barry Lyga, Graphic Novels in Your Media Center: A Definitive Guide (Westport, Conn.: Libraries Unlimited, 2004): 11.

9. Gretchen E. Schwarz, "Graphic Novels for Multiple Literacies," Journal of Adolescent \& Adult Literacy 46, no. 3 (Nov. 2002): 263.

10. Dale Allender, "Popular Culture in the Classroom," English Journal 93 no. 3 (Jan. 2004): 13.

11. Mary Jane Heaney, "Graphic Novels: A Sure Bet for Your Library," Collection Building 26 no. 3 (2007): 72.

12. Katherine T. Bucher and M. Lee Manning, "Bringing Graphic Novels into a School's Curriculum," Clearing House 78 no. 2 (Nov./Dec. 2004): 67.

13. Angelle Barbazon, "University Selects Graphic Novel for Summer Reading," The Daily Reveille, Mar. 28, 2008, 4.

14. Lyga and Lyga, Graphic Novels in Your Media Center, 3-5.

15. Terry Thompson, "Embracing Reluctance When Classroom Teachers Shy Away from Graphic Books," Library Media Connection 25, no. 4 (Jan. 2007): 29.

16. Leckbee, "I Got Graphic," 31.

17. Schwarz, "Graphic Novels for Multiple Literacies," 262.

18. Michael R. Lavin, "Comic Books and Graphic Novels for Libraries: What to Buy," Serials Review 24 no. 2 (Summer 1998): 32.

19. Lyga and Lyga, Graphic Novels in Your Media Center, 2.

20. Thompson, "Embracing Reluctance," 29.

21. Heaney, "Graphic Novels," 74; Leckbee, "I Got Graphic," 30.

22. Thompson, "Embracing Reluctance," 29.

23. Maureen Mooney, "Graphic Novels for the Elementary School Audience," Library Media Connection 23 no. 4 (Jan. 2005): 20.

24. Schwarz, "Graphic Novels for Multiple Literacies," 262.

25. Leckbee, "I Got Graphic," 30.

26. Lyga and Lyga, Graphic Novels in Your Media Center, 13.

27. Schwarz, "Graphic Novels for Multiple Literacies," 264.

28. James Bucky Carter, "Transforming English with Graphic Novels: Moving Toward Our 'Optimus Prime," English Journal 97, no. 2 (Nov. 2007): 50.

29. Thompson, "Embracing Reluctance," 29.

30. Leckbee, "I Got Graphic," 30-31.

31. Ibid., 31 .

32. Nancy Frey and Douglas Fisher, "Using Graphic
Novels, Anime, and the Internet in an Urban High School," English Journal 93 no. 3 (Jan. 2004): 20-21.

33. Ibid., 21-22.

34. Ibid., 23-24.

35. Carter, "Transforming English with Graphic Novels," 50.

36. Ibid., 51.

37. Barbara Brown, "Pairing William Faulkner's Light in August and Art Spiegelman's Maus," in Making American Literatures in High School and College, ed. Anne Ruggles Gere and Peter Shaheen (Urbana, IL: National Council of Teachers of English, 2001): 148-55.

38. Andrea Freud Loewenstein, "Confronting Stereotypes: Maus in Crown Heights," College English 60, no. 4 (Apr. 1998): 396-420.

39. Carter, "Transforming English with Graphic Novels," 49.

40. Ibid., 51.

41. Ibid.

42. Ibid., 51-52

43. Ian Carlson, "Graphic Novels in the Classroom," School Librarians Workshop (special supplement) 29, no. 1 (2008): 22-23.

44. Phillip Crawford, "Beyond Maus: Using Graphic Novels to Support Social Studies Standards," Knowledge Quest 31, no. 4 (Mar./Apr. 2003): 41.

45. National Council for the Social Studies, "Ten Thematic Strands in Social Studies," 2002, http://www .socialstudies.org/standards/strands (accessed Jan. 4, 2009).

46. Crawford, "Beyond Maus," 41.

47. Barbazon, "University Selects Graphic Novel for Summer Reading," 4.

48. Young, "A Collaborative Effort," 16.

49. Gorg Mallia, "Learning from the Sequence: The Use of Comics in Instruction," ImageTexT: Interdisciplinary Comics Studies 3, no. 3 (2007), www.english.ufl.edu/ imagetext/archives/v3_3/mallia/index.shtml (accessed Apr. 28, 2008).

50. Ibid

51. Lavin, "Comic Books and Graphic Novels for Libraries," 43.

52. Lyga and Lyga, Graphic Novels in Your Media Center, 85.

53. Ibid

54. Dan Firrincili, The Wilson Core Collections, 9 min., 15 sec.; WilsonWeb Learning Center, Adobe Captivate, www.hwwilson.com/Documentation/WilsonWeb/ training/Demos/Core/Core_demo.htm (accessed June 30, 2009).

55. Lavin, "Comic Books and Graphic Novels for Libraries," 43.

56. Lyga and Lyga, Graphic Novels in Your Media Center, 85.

57. Daniel D. Barron, "Zap! Pow! Wham!: Comics, Graphic Novels, and Education," School Library Media Activities Monthly 8, no. 3 (Nov. 1991): 50.

58. Barron, "Zap! Pow! Wham!" 48.

59. Shonda Brisco, "Are Graphic Novels Giving You a Headache?" School Library Journal 54, no. 3 (Mar. 2008): 93.

60. Shonda Brisco, "10 Best Digital Resources," School Library Journal 54, no. 5 (May 2008): 54-55.

61. Hollis Margaret Rudiger, "Graphic Novels: Resources," Cooperative Children's Book Center, School of Education, University of Wisconsin-Madison, www.educa tion.wisc.edu/ccbc/books/graphicnovels.asp (accessed Apr. 28, 2008). 


\section{FEATURE}

62. Leslie Bussert, "Comic Books and Graphic Novels: Digital Resources for an Evolving Form of Art and Literature," College \& Research Libraries News 66, no. 2 (Feb. 2005): 103-06, 113; Anne Behler, "Getting Started with Graphic Novels: A Guide for the Beginner," Reference \& User Services Quarterly 46, no. 2 (Winter 2006): 16-21.

63. Rudiger, "Graphic Novels: Resources"; Karen Green, "Columbia University's Graphic Novels Page," Columbia University Libraries, www.columbia.edu/cu/lweb/ eguides/graphic_novels/index.html (accessed Oct. 24, 2008); Diane Schrecker, "Graphic Novels LibGuide," Ashland (Ohio) University Libraries, http://lib guides . ashland.edu/content.php?pid $=25787 \&$ hs $=\mathrm{w}$ (accessed Dec. 12, 2008).

64. GNLIB: Graphic Novels In Libraries, www.angelfire .com/comics/gnlib (accessed April 28, 2008)
65. Carter, "Transforming English with Graphic Novels," 50

66. Lyga and Lyga, Graphic Novels in Your Media Center, 104.

67. "LES Collections Discussion Group," rec. Faye Christenberry, 2008 American Library Association Annual Conference, Anaheim, California, http://iteratures inenglish.pbworks.com/f/Collections+Discussion+20 08+Annual+.pdf (accessed Oct. 8, 2009).

68. Ryan O'Connor, e-mail message to author, July 2, 2009; Young Adult Library Services Association, "Great Graphic Novels for Teens," American Library Association, www.ala.org/yalsa/ggnt (accessed May 4, 2009).

69. Lyga and Lyga, Graphic Novels in Your Media Center, 105; Rudiger, "Graphic Novels: Resources," 2. 